\title{
亞急性骨髄性白血病淋巴腺に於ける骨髄様化発現 と関連性を有すと推さ机る新所見
}

\author{
小 野 興 作

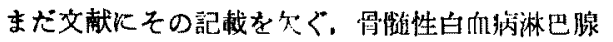 \\ ける多数の淋巴腺とついての組織学的梌索で涩めた \\ に於ける留骷样化が淋巴腺門部から発現するものと \\ のて，これを展示しょうと考える。 \\ 推定される所見を，西急性骨骮性白任病二症例记於
}

\section{腹水腫瘍の抗腫痬性に就いて

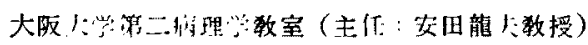 \\ 長谷川悠紀夫 \\ ON ANTI-TUMOR FACTOR IN ASCITIC TUMORS}

By

Yukio Hasegawa

Department of Pathology, Osaka University School of Medicine

(Director. Prof. Tatsno Yasuda)

1. 抗腫湭栍物澌 (因子) 研究の動機.

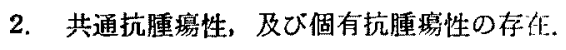

3. 脾脰に於ける抗腫㻛性物質の局在。

4. 腫湯性と血清 $ヘ$ ケロフフリン值との関係。

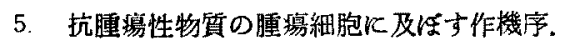

以上の項目に就ての成績を一括報告すると共に, 此等抗腫湯性の研究を通して, 逆に腫海抗原に対す る演者の見解を附言したいと思ち。 